\title{
A Needs Analysis of Postgraduate ESP Students Majoring in Hospitality Management in Iran
}

\author{
Gholamreza Zareian (corresponding author) \\ Department of English Language and Literature, Hakim Sabzevari University, Sabzevar, Iran \\ E-mail: g.zareian@hsu.ac.ir \\ Minoo Pourfarhad \\ Department of English Language and Literature, Hakim Sabzevari University, Sabzevar, Iran \\ E-mail: mnprfrhd@yahoo.com
}

Received: Feb. 25, 2015 Accepted: March 24, 2015 Published: May 1, 2015

doi:10.5296/jse.v5i2.7159 URL: http://dx.doi.org/10.5296/jse.v5i2.7159

\begin{abstract}
The present study aimed at running a needs analysis concerning the needs and requirements of postgraduate ESP students majoring in hospitality management in Iranian universities. To do so, a descriptive survey was designed in which the data was gathered through interviews and the needs analysis questionnaire which was developed and validated for the purpose of the study. The participants of the study consisted of $20 \mathrm{PhD}$ candidates and 30 master's students majoring in hospitality management in Iranian universities. The data gathered by means of the questionnaire were subjected to descriptive analysis and based on the results obtained, the most common issues stated by students were (a) the present status of the English language educational system is not satisfactory; (b) the general English textbooks do not meet the students' needs; (c) students' motivation for the English language is not boosted; (d) the number of hours dedicated to the English language is not adequate; (e) undue emphasis is paid to grammar which has led to the students' learning frustration; (f) the first and the most important needs for the English components are reading comprehension, writing, and translation, vocabulary and essay writing skills are highly required by the postgraduate students; (g) the content of the specialized English textbooks must be more relevant to the students' fields of study and specialized English courses should be taught by the ESP instructors. There is the hope that the findings and results of the present study help EFL curriculum designers and textbook developers to enhance English language instruction at universities in general, and in hospitality management discipline, in particular.
\end{abstract}

Key words: Needs analysis, Postgraduate students, ESP, Hospitality management 


\section{Introduction}

ESP is believed to be a "reaction against conventional foreign language instruction" (Strevens, 1977, p. 145). Needs analysis is part of four absolute characteristics of ESP and is referred to as "needs assessment" in Strevens's definition (Johns \& Dudley-Evans, 1991, p. 116). Strevens (1977) also contends that ESP teaching can be viewed as a response to the requirement to study the learner and to analyze his needs and "to devise means of helping him to learn that which he wishes to learn, not just that which has been defined by some externally-imposed 'general' syllabus" (p. 152). An accurate needs analysis "aims to specify as closely as possible what exactly it is that students have to do through the medium of English" (Robinson, 1991, p. 3). Though some needs analysis research have been done in the Iranian context (Amiri, 2000; Saffarzadeh, 1981; Shahini, 1988), no specific needs analysis have been conducted concerning the ESP needs, requirements, and wants of hospirtality management students at the graduate and post graduate levels. The present article is an attempt to present the results of the need analysis done for the postgraduate ESP students majoring in hospitality management in Iranian context.

\section{Context of the Study}

Iranian students experience almost seven years of English education within the framework of secondary education and spend a lot of time and money on studying English, meanwhile the outcome is not satisfactory (Amiri, 2000). The same trend continues at the university level and higher education centers. Though the importance of the English language in the academic domain cannot be neglected, its training has not been successful for various reasons such as "lack of the required background knowledge among the students, a little time allotted to the English language teaching at the university level" (Shahini, 1988, p. 6), and "paying little attention to writing speaking, and listening skills in university classes" (Farhady, Hezaveh, \& Hedayati, 2010, p.3). Focusing on translation skill is another problem in this regard. "The way English is taught at the universities is often translation oriented because the main objective is to enable students in different majors to read and understand materials written in English in their own majors" (Farhady, et al, 2010, p.13).

The skills Iranian students are at least expected to gain relative mastery over are reading comprehension, translation, and writing (Amiri, 2000). However, Iranian learners in the postgraduate level find such skills problematic as the other skills and show poor performance in this regard. An assumption which could be phrased is students' lack of awareness about their own needs, wants, and requirements. The present study has mainly focused on the perceived needs of postgraduate ESP students majoring in hospitality management in Iranian context.

\section{Literature Review}

West (1994) asserts that needs analysis was generally informal until 1970s and little research was carried out on this concept so that language teachers conducted needs analysis based on some kind of intuitive or informal analysis of students' needs. Richterich and Chancerell (1980) put forward some significant aims of needs analysis: to identify elements which will 
lend themselves to training, to establish the relative importance, and to find out what is indispensable, necessary, or just desirable.

In a survey, Keyoonwong (1998) inquired about the needs and wants of English in the tourism industry in Chiang Mai. The results revealed that the tourism personnel gave priority to speaking and listening skills as most important and necessary, followed by reading, writing, and translation. In fact, the English language proficiency of the staff was not at a satisfactory level from the point of view of employers; the personnel needed more practice regarding the skills of listening, reading, speaking, writing, and translation.

Boonyawattana (1999) also focused on needs of tourism students learning English. The results revealed the importance of speaking as the most needed skill followed by listening, reading, and writing. An English language needs analysis of tour guidance students of Baskent University was carried out by Ekici (2003). Students, English instructors and curriculum coordinators were considered as the respondents in the experiment. The data collection instruments used were the attitude scale, students' needs assessment questionnaire and ESP identification form. The results indicated that speaking, listening, and specialist vocabulary should be given more priority to satisfy the ESP needs of tour guidance students.

This lack of needs analysis studies in literature together with the urgent need to design a syllabus, motivated Orang'i (2013) to conduct a needs analysis to identify the needs of learners pursuing tour guide ESP course in Kenya. According to him, "needs analysis can be done on one or on all the language skills depending on the scope of a particular study" (Orang'i, 2013, p. 35). Thus, he made an attempt to find out the target and language learning needs of tour guide ESP students as perceived by the learners, instructors, and firms' managers. Target situation analysis and present situation analysis (Munby, 1978) and Learning-Centered Approach (Hutchinson \& Waters, 1987) were used as the theoretical frameworks for the study. The results of the questionnaires and interview revealed that the learners considered speaking as the most important skill followed by listening, reading, writing, translation, and specialist vocabulary respectively. Indeed, Orang'i's results corroborated those of Keyoonwong's (1998) as employers were not satisfied with the English proficiency level of their tourism personnel.

Spivack (1997, p. 27) believes that the changes within the tourism and hospitality industry call for "'skill development issues" necessary for the future managers. In order to employ new staff, skills should be given priority (Christou, 1999). Indeed, multicultural abilities and skills are more significant for employees in the hospitality industry (Sigala, 2001). A great number of researchers also believe that as globalization is happening for hospitality, specific skills would be of paramount importance for developing a career (Damitio, 1988; Damitio \& Schmidgall, 1993; Hsu \& Gregory, 1995; Knutson \& Patton, 1992; Ladkin, 1999; Ley, 1980; Riley \& Turam, 1989).

Hotel managers should have multiple technical skills (Baum, 1990; Finegold, Wagner, \& Mason, 2000; Jauhari, 2006). Riley (2005) contends that a Food and Beverage (F\&B) manager must be able to make a decision buying stocks, storing, costing, and processing. Ruddy (1990), Stutts (1995), and Ladkin and Juwaheer (2000) argued that effective 
communication skills are fundamental for career development in the hospitality industry. Technical, leadership and interpersonal skills (Kay \& Russette, 2000) and managerial accounting skills (Damitio \& Schmidgall, 1991) are also declared as significant for hotel managers.

As theoretical aspects are usually dominant in education, Harkison (2004) believes that future managers have to be able to apply theory in practice (work) and expand their work competencies. In this regard, many researchers have affirmed the advantages of internship and Career Educational Programs (CEP) as a cornerstone for hospitality students when they decide to join the industry (Jauhari, 2006; Posey, Carlisle, \& Smellie, 1988; Ricci, 2005).

Previous research has acknowledged that hospitality management degrees usually lack importance in the real world (Harkison, 2004; Steele, 2003). However, Hospitality management students often consider the value of their degrees higher than what their employees do (Collins, 2002; Li \& Kivela, 1989; Raybould \& Wilkins, 2005). Regarding the importance of the needs analysis issue and lack of studies in EFL contexts, the present study makes an effort to analyze the needs of ESP students majoring in hospitality management at graduate level in Iran from the point of view of the students, instructors, and managers in order to fill the perceived gap among theory and practice.

\section{Research Questions}

The main research question of the study was:

What are the perceived needs of the postgraduate ESP students majoring in hospitality management in Iran?

This research question was divided into six minor research questions as follows:

What are the perceived needs of the M.A. students in terms of specific skills in English?

What are the perceived needs of the PhD students in terms of specific skills in English?

What are the perceived needs of the M.A. students in terms of general skills in English?

What are the perceived needs of the PhD students in terms of general skills in English?

Which topics are more interesting for the M.A. students to be included in their course books?

Which topics are more interesting for the $\mathrm{PhD}$ students to be included in their course books?

\section{Method}

\subsection{Participants}

The participants of the study were fifty Iranian EFL postgraduate learners $(20 \mathrm{PhD}$ candidates and 30 M.A. students) of Hospitality Management in Iranian universities, which equals 1/10 of the whole postgraduate students' population in this major. The participants voluntarily took part in the study and filled out the validated needs analysis questionnaire. 


\subsection{Instrumentation}

The data for this study were collected by using questionnaire which is the most common method used for gathering information in most of the survey-based researches. To this end, a needs analysis questionnaire (in Persian), was utilized to cover all the information sought for. The questionnaire was comprised of three major sections namely, students' ability in the English language, students' needs in specific and general skills in English, and topics which are more interesting for the students to be included in their course books. The first section includes five levels of ability including advanced, upper intermediate, lower intermediate, post-beginner, and beginner levels. The second section is comprised of 20 item in two subsets of "Specific Skills in English" including items; 1, 6, 8, 11, 14, 16, 18 and 19, and "General skills needed by hospitality students" including items; 7, 9, 10, 12, 13, 15, 17 and 20. The third part however includes 28 items which cover four areas; area 1 which contains hospitality management including items: $1,6,8,9,10,23,24, \& 25$, area 2 which covers hotel industry and management of hotels, including items: $2,11,20,21,26,27, \& 28$, area 3 which is about main issues of tourism and hospitality, including items: $3,4,5,18,19, \& 22$, and area 4 which focuses on tourism, culture, and history including items: 7, 12, 13,14,15,16, $\& 17$.

\subsection{Questionnaire Construction}

The following steps were taken to construct the questionnaires. First, the questionnaire was devised on the basis of the literature review and the results obtained from a pilot study which was conducted with 30 university students majoring in hospitality management. The instrument for the pilot study was the interview in which the researcher elicited the required information. Second, on the basis of the above-mentioned points, the items of the questionnaire were constructed, and then an impressionistic survey with the scientific board members of the hospitality management in Tehran University was carried out to examine and modify the preliminary versions of the items and determine the face $\&$ content validity of the questionnaires. Third, to make sure that the questionnaire items were unambiguous, clear, understandable, and relevant, another pilot study with 30 randomly selected teaching staff and students including graduate students of hospitality management was conducted at Tabriz University. As a result, some modifications were made on the questionnaire. Forth, because of the interval data, the reliability of the questionnaire was established thorough Cronbach's alpha and $\alpha=0.89$ was obtained.

\subsection{Procedure}

The questionnaire was distributed among the students and in some cases it was emailed to them. Out of 100 questionnaires sent about 70 were returned of which 50 complete ones were selected. The data were analyzed and reported.

\section{Data Analysis and Results}

\section{Research Question 1}

What are the perceived needs of the M.A. students in terms of Specific Skills in English? 
The MA students have identified writing (56.7\%) as their highest need. This was followed by; reading comprehension $(53.3 \%)$, translation $(50 \%)$ and vocabulary and essay writing $(46.7 \%)$. They also attributed great importance to translation and essay writing (50\%) and grammar and reading comprehension (46.7\%). Listening was their least important need (36.7\%) and they also attributed little importance to listening (50\%) and speaking $(36.7 \%)$.

Table 1. MA Students' Specific Needs

\begin{tabular}{|c|c|c|c|c|c|c|c|c|}
\hline & & & \multicolumn{5}{|l|}{ Choices } & \multirow{2}{*}{ Total } \\
\hline & & & Very Little & Little & No Idea & Much & Very Much & \\
\hline \multirow{22}{*}{ Item } & \multirow{2}{*}{ Reading } & Count & 0 & 0 & 0 & 14 & 16 & 30 \\
\hline & & $\%$ within Item & $0.0 \%$ & $0.0 \%$ & $0.0 \%$ & $46.7 \%$ & $53.3 \%$ & $100.0 \%$ \\
\hline & \multirow{2}{*}{ Writing } & Count & 0 & 0 & 0 & 13 & 17 & 30 \\
\hline & & $\%$ within Item & $0.0 \%$ & $0.0 \%$ & $0.0 \%$ & $43.3 \%$ & $56.7 \%$ & $100.0 \%$ \\
\hline & \multirow{2}{*}{ Speaking } & Count & 0 & 11 & 19 & 0 & 0 & 30 \\
\hline & & $\%$ within Item & $0.0 \%$ & $36.7 \%$ & $63.3 \%$ & $0.0 \%$ & $0.0 \%$ & $100.0 \%$ \\
\hline & \multirow{2}{*}{ Listening } & Count & 11 & 15 & 2 & 2 & 0 & 30 \\
\hline & & $\%$ within Item & $36.7 \%$ & $50.0 \%$ & $6.7 \%$ & $6.7 \%$ & $0.0 \%$ & $100.0 \%$ \\
\hline & \multirow{2}{*}{ Vocabulary } & Count & 0 & 0 & 6 & 10 & 14 & 30 \\
\hline & & $\%$ within Item & $0.0 \%$ & $0.0 \%$ & $20.0 \%$ & $33.3 \%$ & $46.7 \%$ & $100.0 \%$ \\
\hline & \multirow{2}{*}{ Grammar } & Count & 0 & 5 & 8 & 14 & 3 & 30 \\
\hline & & $\%$ within Item & $0.0 \%$ & $16.7 \%$ & $26.7 \%$ & $46.7 \%$ & $10.0 \%$ & $100.0 \%$ \\
\hline & \multirow{2}{*}{ Essay Writing } & Count & 0 & 0 & 1 & 15 & 14 & 30 \\
\hline & & $\%$ within Item & $0.0 \%$ & $0.0 \%$ & $3.3 \%$ & $50.0 \%$ & $46.7 \%$ & $100.0 \%$ \\
\hline & \multirow{2}{*}{ RC Journals } & Count & 1 & 1 & 9 & 7 & 12 & 30 \\
\hline & & $\%$ within Item & $3.3 \%$ & $3.3 \%$ & $30.0 \%$ & $23.3 \%$ & $40.0 \%$ & $100.0 \%$ \\
\hline & \multirow{2}{*}{ Tables \& Graphs } & Count & 2 & 4 & 8 & 13 & 3 & 30 \\
\hline & & $\%$ within Item & $6.7 \%$ & $13.3 \%$ & $26.7 \%$ & $43.3 \%$ & $10.0 \%$ & $100.0 \%$ \\
\hline & \multirow{2}{*}{ Summary } & Count & 2 & 3 & 9 & 12 & 4 & 30 \\
\hline & & $\%$ within Item & $6.7 \%$ & $10.0 \%$ & $30.0 \%$ & $40.0 \%$ & $13.3 \%$ & $100.0 \%$ \\
\hline & \multirow{2}{*}{ Translation } & Count & 0 & 0 & 0 & 15 & 15 & 30 \\
\hline & & $\%$ within Item & $0.0 \%$ & $0.0 \%$ & $0.0 \%$ & $50.0 \%$ & $50.0 \%$ & $100.0 \%$ \\
\hline \multirow{2}{*}{ Total } & & Count & 16 & 39 & 62 & 115 & 98 & 330 \\
\hline & & $\%$ within Item & $4.8 \%$ & $11.8 \%$ & $18.8 \%$ & $34.8 \%$ & $29.7 \%$ & $100.0 \%$ \\
\hline
\end{tabular}

\section{Research Question 2}

What are the perceived needs of the PhD students in terms of Specific Skills in English?

The Ph.D. students have identified writing, reading and translation (55\%) as their highest needs. These were followed by vocabulary $(50 \%)$ essay writing $(45 \%)$. The participants also attributed great importance to essay writing grammar and summary writing (50\%). Listening 
was their least important need (30\%) and they also attributed little importance to listening $(50 \%)$ and speaking (35\%).

Table 2. Ph.D. Students' Specific Needs

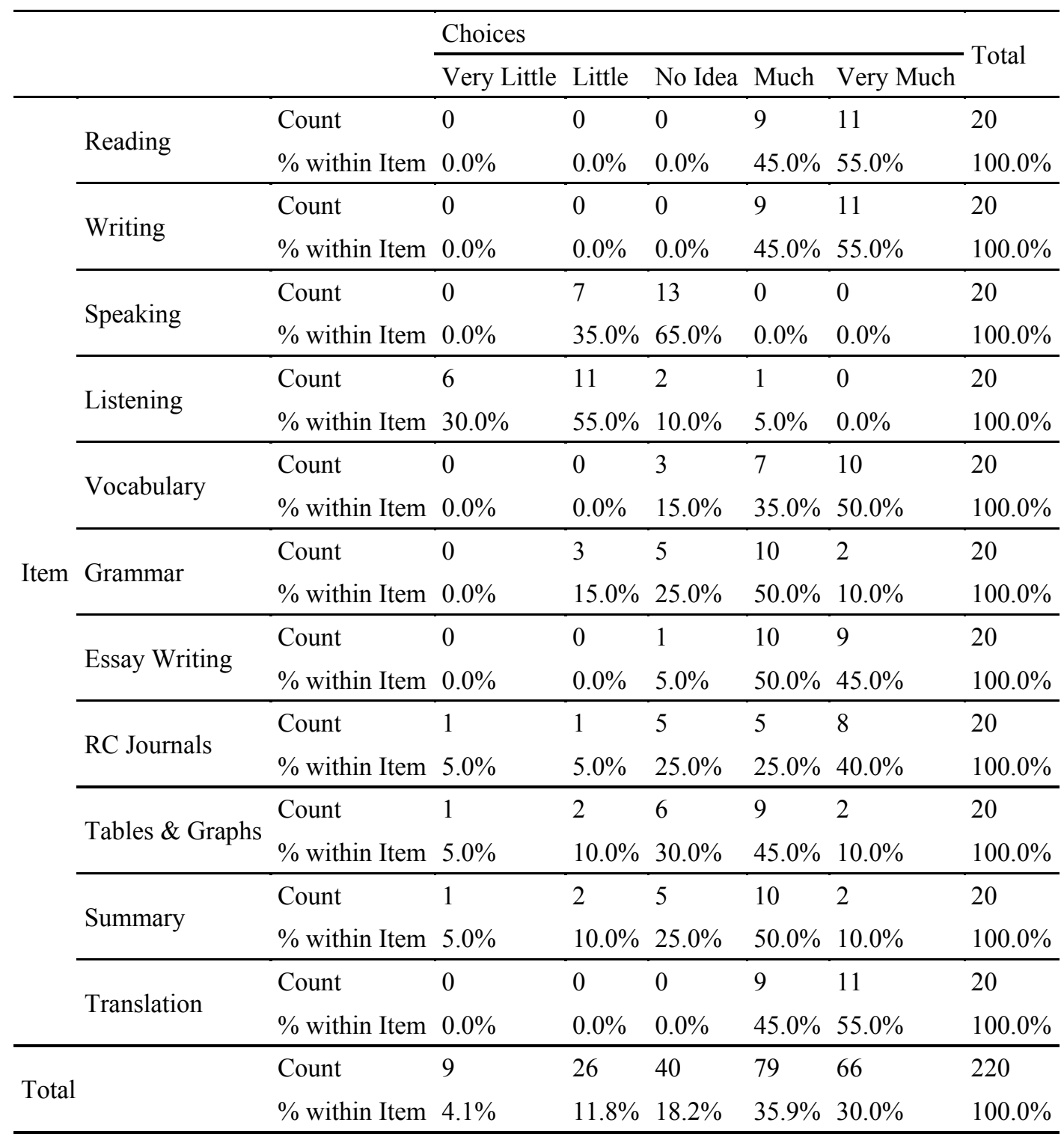

\subsection{Research Question 3}

What are the perceived needs of the M.A. students in terms of General skills in English?

The MA students have identified ability to listen to news (40\%) as their highest general need. This was followed ability to use a dictionary (36.7\%). They also attributed great importance to ability of listening to the news (53.3\%) and writing CV (40\%). Writing emails (63.3\%) and using the internet (40\%) were the least important needs. They also attributed little importance to internet (46.7\%) and learning the Basic English (40\%). 
Table 3. MA Students' General Needs

\begin{tabular}{|c|c|c|c|c|c|c|c|c|}
\hline & & & \multicolumn{5}{|l|}{ Choices } & \multirow{2}{*}{ Total } \\
\hline & & & Very Little & Little & No Idea & Much & Very Much & \\
\hline \multirow{18}{*}{ Item } & \multirow{2}{*}{ Note-Taking } & Count & 16 & 14 & 0 & 0 & 0 & 30 \\
\hline & & $\%$ within Item & $53.3 \%$ & $46.7 \%$ & $0.0 \%$ & $0.0 \%$ & $0.0 \%$ & $100.0 \%$ \\
\hline & \multirow{2}{*}{ Dictionary } & Count & 0 & 2 & 7 & 10 & 11 & 30 \\
\hline & & $\%$ within Item & $0.0 \%$ & $6.7 \%$ & $23.3 \%$ & $33.3 \%$ & $36.7 \%$ & $100.0 \%$ \\
\hline & \multirow{2}{*}{ LC Reports } & Count & 1 & 9 & 18 & 2 & 0 & 30 \\
\hline & & $\%$ within Item & $3.3 \%$ & $30.0 \%$ & $60.0 \%$ & $6.7 \%$ & $0.0 \%$ & $100.0 \%$ \\
\hline & \multirow{2}{*}{ Internet } & Count & 12 & 14 & 4 & 0 & 0 & 30 \\
\hline & & $\%$ within Item & $40.0 \%$ & $46.7 \%$ & $13.3 \%$ & $0.0 \%$ & $0.0 \%$ & $100.0 \%$ \\
\hline & \multirow{2}{*}{$\mathrm{CV}$} & Count & 1 & 1 & 11 & 12 & 5 & 30 \\
\hline & & $\%$ within Item & $3.3 \%$ & $3.3 \%$ & $36.7 \%$ & $40.0 \%$ & $16.7 \%$ & $100.0 \%$ \\
\hline & \multirow{2}{*}{ Presentation } & Count & 0 & 2 & 17 & 11 & 0 & 30 \\
\hline & & $\%$ within Item & $0.0 \%$ & $6.7 \%$ & $56.7 \%$ & $36.7 \%$ & $0.0 \%$ & $100.0 \%$ \\
\hline & \multirow{2}{*}{ News } & Count & 0 & 0 & 2 & 16 & 12 & 30 \\
\hline & & $\%$ within Item & $0.0 \%$ & $0.0 \%$ & $6.7 \%$ & $53.3 \%$ & $40.0 \%$ & $100.0 \%$ \\
\hline & \multirow{2}{*}{ Email } & Count & 19 & 11 & 0 & 0 & 0 & 30 \\
\hline & & $\%$ within Item & $63.3 \%$ & $36.7 \%$ & $0.0 \%$ & $0.0 \%$ & $0.0 \%$ & $100.0 \%$ \\
\hline & \multirow{2}{*}{ Basic English } & Count & 0 & 12 & 18 & 0 & 0 & 30 \\
\hline & & $\%$ within Item & $0.0 \%$ & $40.0 \%$ & $60.0 \%$ & $0.0 \%$ & $0.0 \%$ & $100.0 \%$ \\
\hline \multirow{2}{*}{ Total } & & Count & 49 & 65 & 77 & 51 & 28 & 270 \\
\hline & & $\%$ within Item & $18.1 \%$ & $24.1 \%$ & $28.5 \%$ & $18.9 \%$ & $10.4 \%$ & $100.0 \%$ \\
\hline
\end{tabular}

\subsection{Research Question 4}

What are the perceived needs of the PhD students in terms of General skills in English?

The Ph.D. students have identified ability to use a dictionary and listening to news (40\%) as their highest general needs. They also attributed great importance to ability to listen to news, writing $\mathrm{CV}$ and presentation (40\%). Writing emails (60\%) and note-taking techniques $(55 \%)$ were the least important needs. They also attributed little importance to internet $(50 \%)$ and note-taking $(45 \%)$. 
Table 4. Ph.D. Students' General Needs

\begin{tabular}{|c|c|c|c|c|c|c|c|c|}
\hline & & & \multicolumn{5}{|l|}{ Choices } & \multirow{2}{*}{ Total } \\
\hline & & & Very Little & Little & No Idea & Much & Very Much & \\
\hline \multirow{18}{*}{ Item } & \multirow{2}{*}{ Note-Taking } & Count & 11 & 9 & 0 & 0 & 0 & 20 \\
\hline & & $\%$ within Item & $55.0 \%$ & $45.0 \%$ & $0.0 \%$ & $0.0 \%$ & $0.0 \%$ & $100.0 \%$ \\
\hline & \multirow{2}{*}{ Dictionary } & Count & 0 & 1 & 4 & 7 & 8 & 20 \\
\hline & & $\%$ within Item & $0.0 \%$ & $5.0 \%$ & $20.0 \%$ & $35.0 \%$ & $40.0 \%$ & $100.0 \%$ \\
\hline & \multirow{2}{*}{ LC Reports } & Count & 1 & 5 & 13 & 1 & 0 & 20 \\
\hline & & $\%$ within Item & $5.0 \%$ & $25.0 \%$ & $65.0 \%$ & $5.0 \%$ & $0.0 \%$ & $100.0 \%$ \\
\hline & \multirow{2}{*}{ Internet } & Count & 8 & 10 & 2 & 0 & 0 & 20 \\
\hline & & $\%$ within Item & $40.0 \%$ & $50.0 \%$ & $10.0 \%$ & $0.0 \%$ & $0.0 \%$ & $100.0 \%$ \\
\hline & \multirow{2}{*}{$\mathrm{CV}$} & Count & 1 & 1 & 6 & 8 & 4 & 20 \\
\hline & & $\%$ within Item & $5.0 \%$ & $5.0 \%$ & $30.0 \%$ & $40.0 \%$ & $20.0 \%$ & $100.0 \%$ \\
\hline & \multirow{2}{*}{ Presentation } & Count & 0 & 1 & 11 & 8 & 0 & 20 \\
\hline & & $\%$ within Item & $0.0 \%$ & $5.0 \%$ & $55.0 \%$ & $40.0 \%$ & $0.0 \%$ & $100.0 \%$ \\
\hline & \multirow{2}{*}{ News } & Count & 0 & 0 & 1 & 11 & 8 & 20 \\
\hline & & $\%$ within Item & $0.0 \%$ & $0.0 \%$ & $5.0 \%$ & $55.0 \%$ & $40.0 \%$ & $100.0 \%$ \\
\hline & \multirow{2}{*}{ Email } & Count & 12 & 8 & 0 & 0 & 0 & 20 \\
\hline & & $\%$ within Item & $60.0 \%$ & $40.0 \%$ & $0.0 \%$ & $0.0 \%$ & $0.0 \%$ & $100.0 \%$ \\
\hline & \multirow{2}{*}{ Basic English } & Count & 0 & 7 & 13 & 0 & 0 & 20 \\
\hline & & $\%$ within Item & $0.0 \%$ & $35.0 \%$ & $65.0 \%$ & $0.0 \%$ & $0.0 \%$ & $100.0 \%$ \\
\hline \multirow{2}{*}{ Total } & & Count & 33 & 42 & 50 & 35 & 20 & 180 \\
\hline & & $\%$ within Item & $18.3 \%$ & $23.3 \%$ & $27.8 \%$ & $19.4 \%$ & $11.1 \%$ & $100.0 \%$ \\
\hline
\end{tabular}

\subsection{Research Question 5}

Which topics are more interesting for the Ph.D. students to be included in their course books?

Majority of the Ph.D. respondents ( $80 \%)$ believed that issues related to hospitality and management should be included in their textbooks. 20 percent of respondents have expressed no idea and no one disagreed with the inclusion of hospitality and management in their textbooks. 


\section{Macrothink}

Journal of Studies in Education

ISSN 2162-6952

2015, Vol. 5, No. 2

Table 5. Frequencies and Percentages; Topics to Be Included in Textbooks (PhD Students)

\begin{tabular}{llllll}
\hline \multirow{2}{*}{ MA } & & \multicolumn{2}{l}{ Choices } & & \\
\cline { 2 - 5 } Hospitality \& Management & & Disagree & No Idea & Agree \\
\hline \multirow{2}{*}{ Hotel Industry \& Management } & Count & 0 & 32 & 128 & 160 \\
& \% within Section & $0.0 \%$ & $20.0 \%$ & $80.0 \%$ & $100.0 \%$ \\
\hline \multirow{2}{*}{ Main Issues in Tourism and Management } & Count & 0 & 57 & 83 & 140 \\
& \% within Section & $0.0 \%$ & $40.7 \%$ & $59.3 \%$ & $100.0 \%$ \\
\hline \multirow{2}{*}{ Tourism, Culture and History } & \% within Section & $0.0 \%$ & $75.0 \%$ & $25.0 \%$ & $100.0 \%$ \\
\hline \multirow{2}{*}{ Total } & Count & 75 & 55 & 10 & 140 \\
& $\%$ within Section & $53.6 \%$ & $39.3 \%$ & $7.1 \%$ & $100.0 \%$ \\
\hline
\end{tabular}

A lower percentage $(59.3 \%)$ believed that issues related to hotel industry and management should be included in their textbooks, while about 40 percent of the respondents had no idea about this issue. A low percentage (25\%) believed that main issues related to tourism and management should be included in the textbooks. Majority of the respondents (75\%) had no idea, and finally; majority of the respondents (53.6\%) disagreed with the inclusion of topics related to tourism, culture and history in their textbooks while 39.3 percent had no idea and only 7.1 percent agreed with this idea.

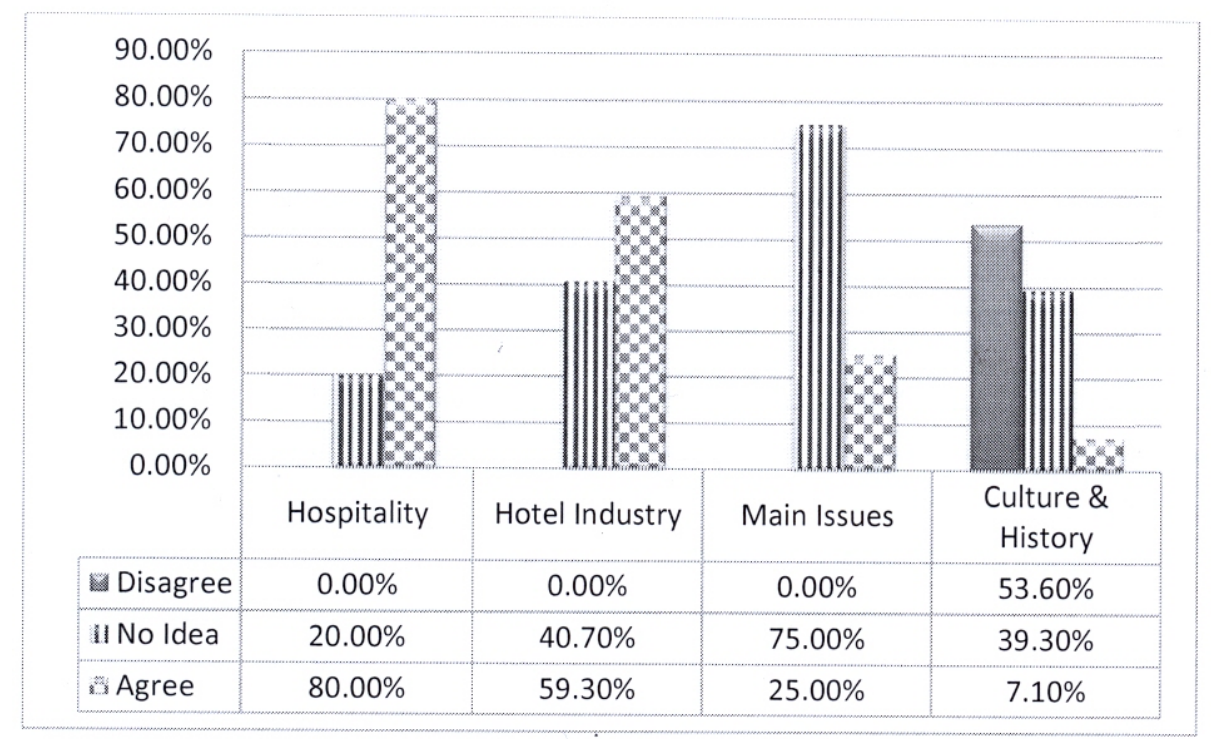

Figure 1. Ph.D. Students' Favored Topics

\subsection{Research Question 6}

Which topics are more interesting for the MA students to be included in their course books? 


\section{Macrothink}

Journal of Studies in Education

ISSN 2162-6952

2015, Vol. 5, No. 2

The majority of the MA respondents (96.6\%) believed that issues related to hospitality and management should be included in their textbooks. Only 3.4 percent had no idea about this issue.

Table 6. Frequencies and Percentages; Topics to Be Included in Textbooks (MA. Students)

\begin{tabular}{|c|c|c|c|c|c|}
\hline \multirow[b]{2}{*}{ Ph.D. } & & \multicolumn{3}{|l|}{ Choices } & \multirow{2}{*}{ Total } \\
\hline & & Disagree & No Idea & Agree & \\
\hline \multirow{2}{*}{ Hospitality \& Management } & Count & 0 & 8 & 225 & 233 \\
\hline & $\%$ within Section & $0.0 \%$ & $3.4 \%$ & $96.6 \%$ & $100.0 \%$ \\
\hline \multirow{2}{*}{ Hotel Industry \& Management } & Count & 0 & 126 & 84 & 210 \\
\hline & $\%$ within Section & $0.0 \%$ & $60.0 \%$ & $40.0 \%$ & $100.0 \%$ \\
\hline \multirow{2}{*}{ Main Issues in Tourism and Management } & Count & 0 & 138 & 42 & 180 \\
\hline & $\%$ within Section & $0.0 \%$ & $76.7 \%$ & $23.3 \%$ & $100.0 \%$ \\
\hline \multirow{2}{*}{ Tourism, Culture and History } & Count & 100 & 96 & 14 & 210 \\
\hline & $\%$ within Section & $47.6 \%$ & $45.7 \%$ & $6.7 \%$ & $100.0 \%$ \\
\hline \multirow{2}{*}{ Total } & Count & 100 & 368 & 365 & 833 \\
\hline & $\%$ within Section & $12.0 \%$ & $44.2 \%$ & $43.8 \%$ & $100.0 \%$ \\
\hline
\end{tabular}

A lower percentage $(40 \%)$ believed that issues related to hotel industry and management should be included in their textbooks, while about 60 percent of the respondents had no idea about this issue. A low percentage $(23.3 \%)$ believed that main issues related to tourism and management should be included in their textbooks. Majority of the respondents $(76.7 \%)$ had no idea. And finally; majority of the respondents $(47.6 \%)$ disagreed with the inclusion of topics related to tourism, culture and history in their textbooks while 45.7 percent had no idea and only 6.7 percent agreed with this idea.

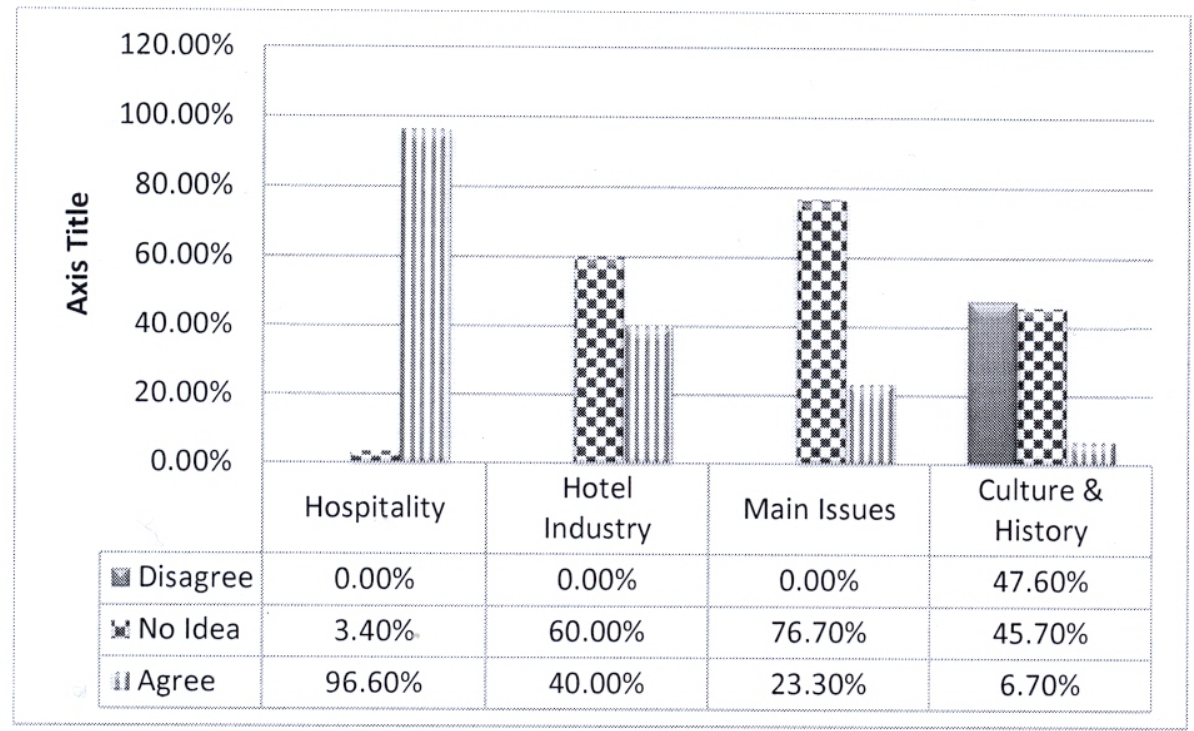

Figure 2. MA Students' Favored Topics 


\section{Reliability Indices}

The Cronbach's alpha reliability indices for the needs and topics were .74 and .91.

Reliability Statistics

\begin{tabular}{lll}
\hline & $\begin{array}{l}\text { Cronbach's } \\
\text { Alpha }\end{array}$ & N of Items \\
\hline Needs & .746 & 20 \\
\hline Topics & .917 & 28 \\
\hline
\end{tabular}

Table 7. Item * Choices Crosstabulation \% within Item

\begin{tabular}{|c|c|c|c|c|c|c|c|}
\hline & & \multicolumn{5}{|l|}{ Choices } & \multirow{2}{*}{ Total } \\
\hline & & Very Little & Little & No Idea & Much & Very Much & \\
\hline \multirow{9}{*}{ Item } & 1 & $55.0 \%$ & $45.0 \%$ & & & & $100.0 \%$ \\
\hline & 2 & & $5.0 \%$ & $20.0 \%$ & $35.0 \%$ & $40.0 \%$ & $100.0 \%$ \\
\hline & 3 & $5.0 \%$ & $25.0 \%$ & $65.0 \%$ & $5.0 \%$ & & $100.0 \%$ \\
\hline & 4 & $40.0 \%$ & $50.0 \%$ & $10.0 \%$ & & & $100.0 \%$ \\
\hline & 5 & $5.0 \%$ & $5.0 \%$ & $30.0 \%$ & $40.0 \%$ & $20.0 \%$ & $100.0 \%$ \\
\hline & 6 & & $5.0 \%$ & $55.0 \%$ & $40.0 \%$ & & $100.0 \%$ \\
\hline & 7 & & & $5.0 \%$ & $55.0 \%$ & $40.0 \%$ & $100.0 \%$ \\
\hline & 8 & $60.0 \%$ & $40.0 \%$ & & & & $100.0 \%$ \\
\hline & 9 & & $35.0 \%$ & $65.0 \%$ & & & $100.0 \%$ \\
\hline Total & & $18.3 \%$ & $23.3 \%$ & $27.8 \%$ & $19.4 \%$ & $11.1 \%$ & $100.0 \%$ \\
\hline
\end{tabular}

\section{Conclusion}

Both MA and $\mathrm{PhD}$ students have identified writing, reading and translation as their highest needs. This was followed by vocabulary and essay writing. They also attributed great importance to essay writing and summary writing. Listening was their least important need and they also attributed little importance to listening and speaking. Writing emails and using the internet were among the least important needs perceived. Majority of the Ph.D. and M.A. respondents believed that issues related to hospitality and management issues should be included in their textbooks. A minor percentage of respondents expressed no idea and no one disagreed with the inclusion of hospitality and management concepts in the textbooks. A lower percentage believed that issues related to hotel industry and management should be included in their textbooks and the same was mentioned about the issues related to tourism and management to be included in the textbooks. A lower percentage believed that issues related to hotel industry and management should be included in the textbooks while majority of the respondents disagreed with the inclusion of topics related to tourism, culture and history in their textbooks.

The most common issues stated by students were: a) the present status of the English language educational system is not satisfactory; b) the general English textbooks do not meet the students' needs; c) students' motivation for the English language is not boosted; d) the 
credit/hour dedicated to the English language is not adequate; e) undue emphasis is paid to 'Grammar' which has led to the students' learning frustration; f) the first and the most important needs to the English components are: 'Reading Comprehension', 'Writing', and 'Translation', moreover, 'Vocabulary' and 'Essay Writing' skills are highly required by the postgraduate students; g) the content of the specialized English textbooks must be more relevant to the students' fields of study and Specialized English courses should be taught by the ESP instructors. There is the hope that the findings and results of the present study help EFL curriculum designers and textbook developers to enhance English language instruction at Universities in general, and in hospitality management discipline, in particular.

\section{References}

Amiri, M. (2000). A study on the English language programs at B.A. level at Tehran universities. Master's thesis, Allameh Tabatabai University, Tehran, Iran.

Baum, T. (1990). Competencies for hotel management: Industry expectations of education. International Journal of Contemporary Hospitality Management, 2(4), 13-16. http://dx.doi.org/10.1108/09596119010135190

Boonyawattana, P. (1999). Needs analysis of English in tourism business. Chiang Mai. Chiang Mai: Chiang Mai University.

Christou, E. (1999). Hospitality management education in Greece: Overview and qualitative assessment. Tourism Management, 20(6), 683-691. http://dx.doi.org/10.1016/S0261-5177(99)00039-4

Collins, A. B. (2002). Are we teaching what we should? Dilemmas and problems in tourism and hospitality management education. Tourism Analysis, 7(2), 151-163.

Damitio, J. W. (1988). Importance of managerial accounting skills to lodging managers. Hospitality Education and Research Journal, 12(2), 287-292.

Damitio, J. W., \& Schmidgall, R. (1991). A comparison of hospitality executives', educators', and students' views on the importance of accounting skills. International Journal of Hospitality Management, 10(3), 219-228. http://dx.doi.org/10.1016/0278-4319(91)90055-M

Damitio, J. W., \& Schmidgall, R. (1993). Hospitality professional responses to ethical situations. The Cornell Hotel and Restaurant Administrative Quarterly, 34(4), 40-43.

Ekici, N. (2003). A needs assessment study on English language needs of the Tour Guidance students of Faculty of Applied Sciences at Baskent University. Master's Thesis, Baskent University.

Farhady, H., Hezaveh, F. S., \& Hedayati, H. (2010). Reflections on foreign language education in Iran. TESL-EJ, 13(4), 1-18.

Finegold, D., Wagner, K., \& Mason, G. (2000). National skill-creation systems and career paths for service workers: Hotels in the United States, Germany and the United Kingdom. 
International Journal of Human Resource Management, 11(3), 497-516. http://dx.doi.org/10.1080/095851900339738

Harkison, T. (2004). Hospitality Degrees in New Zealand: Exploratory Research. Master's Thesis. Massey University, Wellington.

Hsu, J. F., \& Gregory, S. (1995). Developing future hotel managers in Taiwan: From an industry viewpoint. International Journal of Hospitality Management, 14(3/4), 261-269. http://dx.doi.org/10.1016/0278-4319(95)00029-1

Hutchinson, T., \& Waters, A. (1987). English for specific purposes: A learning-centred approach. Cambridge: Cambridge University Press. http://dx.doi.org/10.1017/CBO9780511733031

Jauhari, V. (2006). Competencies for a career in the hospitality industry: An Indian perspective. International Journal of Contemporary Hospitality Management, 18(2), 123-134. http://dx.doi.org/10.1108/09596110610646673

Johns, A. M., \& Dudley - Evans, T. O. N. Y. (1991). English for specific purposes: International in scope, specific in purpose. TESOL Quarterly, 25(2), 297-314. http://dx.doi.org/10.2307/3587465

Kay, C., \& Russette, J. (2000). Hospitality-management competencies. Cornell Hotel and Restaurant Administration Quarterly, 51, 52-63. http://dx.doi.org/10.1177/001088040004100217

Keyoonwong, S. (1998). A survey of needs and wants of English in tourism career in Chiang Mai. Chiang Mai: Chiang Mai University.

Knutson, B. J., \& Patton, M. E. (1992). How prepared am I to succeed in the hospitality industry? What the students are telling us. Hospitality and Tourism Education, 4(3), 38-43.

Ladkin, A. (1999). Hotel general managers: A review of prominent research themes. International Journal of Tourism Research, 1(3), 167-193. http://dx.doi.org/10.1002/(SICI)1522-1970(199905/06)1:3<167::AID-JTR149>3.0.CO;2-S

Ladkin, A., \& Juwaheer, T. (2000). The career paths of hotel general managers in Mauritius. International Journal of Contemporary Hospitality Management, 12(2), 119-125. http://dx.doi.org/10.1108/09596110010309925

Ley, D. A. (1980). The effective GM: Leader or entrepreneur? The Cornell Hotel and Restaurant Administrative Quarterly, 66-67. http://dx.doi.org/10.1177/001088048002100316

Li, L., \& Kivela, J. (1989). Different perceptions between hotel managers and students regarding levels of competency demonstrated by hospitality degree graduates. Australian Journal of Hospitality Management, 5(2), 47-54.

Munby, J. (1978). Communicative Syllabus Design. Cambridge: Cambridge University Press. 
Orang'i, O. D. (2013). A needs analysis of business English programme for tour guide diploma students in Kenya. Masers' Thesis, Kenyatta University.

Posey, L. O., Carlisle, K. E., \& Smellie, D. C. (1988). An internship case study: How internships can benefit the student, the university, and the organization. Training and Development Journal, 42(2), 59-64.

Raybould, M., \& Wilkins, H. (2005). Over qualified and under experienced: Turning graduates into hospitality managers. International Journal of Contemporary Hospitality Management, 17(3), 203-216. http://dx.doi.org/10.1108/09596110510591891

Ricci, P. (2005). A comparative analysis of job competency expectations for new hires: The relative value of a hospitality management degree. Doctor of Education Dissertation. University of Central Florida Orland, Florida.

Richterich, R., \& Chancerel, J. L. (1980). Identifying the needs of adults learning a foreign language. Oxford: Pergamon Press.

Riley, M. (2005). Viewpoint food and beverage management: A review of change. International Journal of Contemporary Hospitality Management, 17(1), 88-93. http://dx.doi.org/10.1108/09596110510577707

Riley, M., \& Turam, K. (1989). The career paths of UK hotel managers: A developmental approach. Signet Quarterly, 1(1), 1-13.

Robinson, P. (1991). ESP today: A practitioner's guide. New York: Prentice Hall.

Ruddy, J. (1990). Patterns of hotel management development in South East Asia. Hospitality Research Journal, 14(2), 349-361.

Saffarzadeh, T. (1981). An introduction to the English books published by SAMT. Tehran: SAMT Publications.

Shahini, G. H. (1988). A needs assessment for EFL courses at Shiraz University. M.A. thesis. Shiraz University, Shiraz, Iran.

Sigala, M. (2001, May). Measuring students' variables for developing e-learning platforms.

Paper presented at the First National Greek Conference on Open and Distance Education, Greek Open University, Patras, Greece, 24-27 May.

Spivack, S. (1997). A consensus model approach for assessing gaps between education system output and human resource demands in the tourism and hospitality sector to aid in the attainment of quality service goals. Doctoral dissertation, University of Buckingham, Buckingham.

Steele, R. (2003). Career analysis: A study of low, mid, and high level managers in the hotel industry in Auckland, New Zealand. Paper presented at the Sociological Association of Aotearoa New Zealand Annual Conference, 9-11 December 2003, Auckland University of Technology, Auckland. 


\section{Macrothink}

Journal of Studies in Education

ISSN 2162-6952 2015, Vol. 5, No. 2

Strevens, P. (1977). Special-purpose language learning: A perspective. Language Teaching, 10, 145-163. http://dx.doi.org/10.1017/S0261444800003402

Stutts, A. (1995). Viewpoint: Higher education in hospitality management. International Journal of Contemporary Hospitality Management, 7(6), 2-3.

West, R. (1994). Needs analysis in language teaching. Language Teaching, 27, 1-9. http://dx.doi.org/10.1017/S0261444800007527 